\title{
Experimental analysis and finite element modeling of the piston-on-three balls testing of Y-TZP ceramic
}

\section{(Analise experimental e modelamento por elementos finitos de ensaio de flexão biaxial de cerâmica Y-TZP)}

\author{
P. C. Silva', L. P. Moreira', M. F. R. P. Alves ${ }^{2}$, L. Q. B. Campos ${ }^{2}$, B. G. Simba ${ }^{3}$, C. dos Santos S $^{1,2 *}$ \\ ${ }^{1}$ Universidade Federal Fluminense, Escola de Engenharia Industrial Metalúrgica de Volta Redonda, \\ Av. dos Trabalhadores 420, 27255-125, Volta Redonda, RJ, Brazil \\ ${ }^{2}$ Universidade do Estado do Rio de Janeiro, Faculdade de Tecnologia de Resende, Resende, RJ, Brazil \\ ${ }^{3}$ Universidade Estadual Paulista, Faculdade de Engenharia de Guaratinguetá, Guaratinguetá, SP, Brazil
}

\begin{abstract}
The objectives of this study were to characterize and evaluate the physical and mechanical properties of an experimental zirconia for dental application and compare the biaxial flexural strength results with the finite element simulation (FEM). Yttria-stabilized tetragonal zirconia polycrystal (Y-TZP) ceramic samples were sintered at $1475{ }^{\circ} \mathrm{C} / 2 \mathrm{~h}$ and characterized by X-ray diffraction, scanning electron microscopy, relative density, flexural strength using piston-on-three balls (P-3B) test and Young's modulus. From the flexural strength results, numerical simulations were performed using Abaqus software. The complete model used 70216 elements, considering the components of the test. The results indicated full densification of sintered samples, $\mathrm{ZrO}_{2}$-tetragonal and $\mathrm{ZrO}_{2}$-cubic as crystalline phases, and average grain size of $0.6 \pm 0.2 \mu \mathrm{m}$. Mechanical characterization of sintered samples indicated Young's modulus of $195 \pm 4 \mathrm{GPa}$, flexural strength of $1191 \pm 9 \mathrm{MPa}$ and Weibull modulus $\mathrm{m}=16.3$. FEM simulation indicated a flexural strength close to $1100 \mathrm{MPa}$, with a difference lower than $7 \%$ in relation to the experimental results. The results were compared associating the physical and mechanical properties of Y-TZP with its intrinsic phenomena such as $t \rightarrow m$ transformation and ferroelastic domain.
\end{abstract}

Keywords: Y-TZP ceramics, mechanical properties, flexural strength, piston-on-three balls (P-3B) test, FEM simulation, toughening mechanisms.

\begin{abstract}
Resumo
O objetivo deste estudo foi caracterizar e avaliar as propriedades físicas e mecânicas de uma zircônia experimental para aplicação odontológica e comparar os resultados da resistência à flexão biaxial com a simulação de elementos finitos (MEF). Amostras de zircônia tetragonal estabilizada com ítria $(Y-T Z P)$ foram sinterizadas a $1475{ }^{\circ} \mathrm{C} / 2$ h e caracterizadas por difração de raios $X$, microscopia eletrônica de varredura, densidade relativa, resistência à flexão usando teste de pistão em três bolas $(P-3 B)$ e módulo de Young. A partir dos resultados de resistência à flexão, foram realizadas simulações numéricas utilizando o software Abaqus. O modelo completo utilizou 70216 elementos. Os resultados apontaram para densificação total em amostras sinterizadas, $\mathrm{ZrO}_{2}$

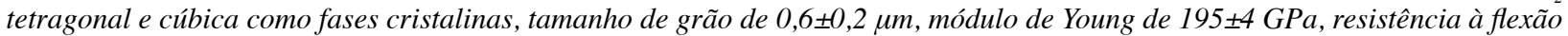
de 1191 \pm 9 MPa e módulo de Weibull m=16,3. A simulação numérica indicou uma resistência à flexão próxima de 1100 MPa, com diferença menor que $7 \%$ em relação aos resultados experimentais. Os resultados foram comparados associando as propriedades físicas e mecânicas de Y-TZP com seus fenômenos intrínsecos, como a transformação $t \rightarrow m$ e o domínio ferroelástico.

Palavras-chave: zircônia, resistência à flexão, teste de pistão em três bolas $(P-3 B)$, simulação MEF, mecanismos de tenacificação.
\end{abstract}

\section{INTRODUCTION}

Flexural strength is one of the main mechanical properties evaluated in structural ceramics [1-3]. Ceramics have been employed as indirect restorative materials in dentistry due to their ability to mimic the dental structure and adequate mechanical properties. These materials could be classified

*claudineisvr@gmail.com

Dhttps://orcid.org/0000-0002-9398-0639 according to their microstructure and, consequently, to the masticatory stresses that they can support $[4,5]$. The flexural tests have the objective of determining the fracture resistance of dental ceramics in the laboratory and have clinical relevance, since they serve to assess the quality control of different materials, aiming to adapt their use to the different dental clinical demands, such as unitary or multielement prostheses, veneers, onlays or inlays [4, 6]. Currently, dental indirect restorative materials, such as yttria-stabilized tetragonal zirconia polycrystals, Y-TZP, are manufactured 
in pre-processed blank (discs or other geometries) for machining in $\mathrm{CAD} / \mathrm{CAM}$ (computer-aided design/computeraided manufacturing) milling. The processing of materials in a controlled industrial environment reduces possible sources of defects created during intermediate laboratory steps (such as related to manipulation of suspensions of ceramic powders and sintering) $[4,6-8]$.

For the determination of limits for the use of ceramics in dentistry, depending on the final application, the international standard ISO 6872-15 - Dentistry-ceramic materials [5], allows using 3-point and 4-point bending tests as well as biaxial tests such as piston-on-three balls (P-3B) for determination of the flexural strength of dental ceramics. Due to the complex geometries of the human dental anatomy and searching for standardization of the results of the mechanical testing, during several years the 3-point (3-P) or 4-point (4$\mathrm{P}$ ) bending tests were used to determine the flexural strength of dental ceramics. However, in these tests, inaccuracies in the articulation of the bending devices, positioning and parallelism of the samples associated with the friction and shear edge effects, can lead to considerable percentage errors in determining the strength, especially when rectangular bars are used as geometry for the specimens. Besides these error sources, samples are still prone to damage during their preparation, such as chip formation of sharp corners, which can cause irregular stress distributions during the test $[9,10]$. In this context, the main advantages of obtaining the flexural strength in ceramics using the piston-on-three balls (P-3B) tests [10] are based on the possibility of series production of specimens, subtracted by CAD/CAM milling, from the same source (same pre-sintered block), preserving the intrinsic characteristics of the material in the batch analyzed.

Previous studies [9-11] report the simulation of stresses during flexural tests for B-3B (ball-on-three-ball) configurations, but despite the ISO 6872 standard allows the use of P-3B flexural tests to indicate the flexural strength of dental ceramics, numerical simulations involving methods of finite elements of P-3B devices have not been observed in the recent literature. The objective of this study was to compare the results of the flexural test using the piston-onthree balls (P-3B) test with simulation results using finite element modelling (FEM), associated with the physical and mechanical properties of Y-TZP along with its intrinsic phenomena such as $\mathrm{t} \rightarrow \mathrm{m}$ (tetragonal to monoclinic) transformation and ferroelastic domain.

\section{EXPERIMENTAL}

Processing: $\mathrm{ZrO}_{2}-3 \mathrm{~mol} \% \mathrm{Y}_{2} \mathrm{O}_{3}$ (Y-TZP, Zpex, Tosoh, Japan) was used as a starting powder. 23 disc specimens (final dimensions after sintering of $15.0 \mathrm{~mm}$ diameter and $1.34 \pm 0.03 \mathrm{~mm}$ thickness) were cold uniaxial pressed at 100 MPa for $60 \mathrm{~s}$. The discs were sintered in a $\mathrm{MoSi}_{2}$ furnace (F1650, Maitec, Brazil), with a heating rate of $1{ }^{\circ} \mathrm{C} / \mathrm{min}$ up to $700{ }^{\circ} \mathrm{C}$ and $5^{\circ} \mathrm{C} / \mathrm{min}$ up to $1475^{\circ} \mathrm{C}$, with an isothermal holding time of $2 \mathrm{~h}$. The cooling rate adopted was $5^{\circ} \mathrm{C} / \mathrm{min}$ to room temperature.
Characterizations: the apparent density of sintered Y-TZP samples was determined by the immersion method, using Archimedes' principle. Relative density was then calculated from the relation between apparent density and real density $\left(6.05 \mathrm{~g} / \mathrm{cm}^{3}\right)$. Crystalline phases of the sintered samples were determined by X-ray diffraction (XRD) in a Shimadzu XRD-6000 diffractometer, using $\mathrm{CuK} \alpha$ radiation in the $2 \theta$ range from $20^{\circ}$ to $80^{\circ}$, step width of $0.05^{\circ}$ and an exposure time of $3 \mathrm{~s} /$ count. The crystalline peaks were identified by comparison with the Powder Diffraction Files (PDF) database from the International Centre for Diffraction Data (ICDD) [12]. Rietveld refinement [13] analysis was made employing the X'pert Highscore software (Phillips). For the calculations of structural parameters, it was adopted that the peaks presented a pseudo-Voigt type shape; the weight percentage $\left(\mathrm{W}_{\mathrm{p}}\right)$ of a crystalline phase $\mathrm{p}$ in a multiphase material composed by $n$ phases was calculated as [14]:

$$
\mathrm{W}_{\mathrm{p}}=\frac{\mathrm{S}_{\mathrm{p}} \cdot(\mathrm{Z} \cdot \mathrm{M} \cdot \mathrm{V})_{\mathrm{p}}}{\sum_{\mathrm{i}=1}^{\mathrm{n}} \mathrm{S}_{\mathrm{i}} \cdot(\mathrm{Z} \cdot \mathrm{M} \cdot \mathrm{V})_{\mathrm{i}}} \cdot 100 \%
$$

using Rietveld scale factor (S), number of formula units per unit cell (Z), mass of each formula unit (M) and unit-cell volume $(\mathrm{V})$. As the specimens were sintered in a biphasic region $\left(\mathrm{ZrO}_{2}\right.$-tetragonal $+\mathrm{ZrO}_{2}$-cubic) and both structures are remarkably difficult to be distinguished, all the refinements were conducted employing the methodology proposed in [15] to calculate the lattice parameters and quantify the yttrium concentration $\left[\mathrm{YO}_{1.5}\right](\mathrm{mol} \%)$ in each phase, based on equations:

$$
\begin{aligned}
& \mathrm{a}_{\mathrm{t}} \cdot \sqrt{ } 2=5.078+3 \cdot 767 \cdot 10^{-3} \cdot\left[\mathrm{YO}_{1.5}\right] \\
& \mathrm{c}_{\mathrm{t}}=5.193+2.903 \cdot 10^{-3} \cdot\left[\mathrm{YO}_{1.5}\right] \\
& \mathrm{a}_{\mathrm{c}}=5.113+1.711 \cdot 10^{-3} \cdot\left[\mathrm{YO}_{1.5}\right]
\end{aligned}
$$

The sintered specimens were ground and thoroughly polished using a sequence $9 \rightarrow 6 \rightarrow 1 \mu \mathrm{m}$ diamond suspensions after sintering. After polishing, all specimens (discs) were heat-treated at $1250{ }^{\circ} \mathrm{C} / 30 \mathrm{~min}$ to recover the tetragonal$\mathrm{ZrO}_{2}$ phase previously transformed to monoclinic $\mathrm{ZrO}_{2}$ during polishing step [16]. The specimens were cleaned with acetone and then in isopropyl alcohol in an ultrasonic bath for $10 \mathrm{~min}$. The microstructure of the specimens was observed by scanning electron microscopy (SEM) in a Jeol JSM-6490 microscope. Samples were thermally etched at $1400{ }^{\circ} \mathrm{C} / 15 \mathrm{~min}$, and grain size was measured using Image J software. Furthermore, surface roughness, $R_{a}$, was obtained using a 3D optical interferometer (New View 7100, Zygo).

Mechanical properties: hardness [17] and fracture toughness $\left(\mathrm{K}_{\mathrm{c}}\right)$ were determined by the Vickers indentation method, using a Vickers microhardness tester (F100, Time, China). In each sample, 5 indentations were measured under a load of $9.8 \mathrm{~N} / 30 \mathrm{~s}$. The fracture toughness was then calculated using an equation proposed in [18]. 
Young's modulus was measured by IET (impulse excitation technique) with a Sonelastic apparatus (ATCP, Brazil). The specimens used in measurements were discs $(15 \mathrm{~mm}$ diameter x $1.3 \mathrm{~mm}$ thickness). The impulser consisted of a steel ball of $5.5 \mathrm{~mm}$ diameter that was glued to a flexible polymer rod. The specimens were struck elastically on an anti-nodal point. The vibration was recorded using a microphone. The measurements were repeated until each sample in consecutive readings achieved a variation of less than $2 \mathrm{~Hz}$. Calculation of Young's modulus was according to ASTM E1876-15 standard [19] based on the theory of free vibrations of elastic bodies. The biaxial flexural strength of the discs was measured by a piston-on-three-ball (P-3B) test using a universal testing machine (mod. 1000, Emic, Brazil) according to ISO 687215 standard [5]. Each disc was centrally placed on the 3 steel balls with $3.5 \mathrm{~mm}$ diameter, positioned in a supporting circle with a diameter of $11 \mathrm{~mm}$. The analyzed surface of the disc sample corresponded to the bottom surface which was submitted to a tensile stress state, while the other surface was loaded with a flat punch with diameter of $1.4 \mathrm{~mm}$ at a constant cross-head speed of $0.5 \mathrm{~mm} / \mathrm{min}$ until fracture. A thin plastic film was placed between the Y-TZP samples and the flattened ball piston, to distribute the load evenly. All dimensions of the specimens were measured not allowing variations above 0.01 $\mathrm{mm}$. The maximum flexural strength $\left(\sigma_{\mathrm{f}}, \mathrm{MPa}\right)$ was calculated by:

$$
\begin{aligned}
& \sigma_{\mathrm{f}}=\frac{-0.2387 \cdot F \cdot(X-Y)}{b^{2}} \\
& X=(1+v) \cdot \ln \left(r_{2} / r_{3}\right)^{2}+[(1-v) / 2] \cdot\left(r_{2} / r_{3}\right)^{2} \\
& Y=(1+v) \cdot\left[1+\ln \left(r_{1} / r_{3}\right)^{2}\right]+(1-v) \cdot\left(r_{1} / r_{3}\right)^{2}
\end{aligned}
$$

where $\mathrm{F}$ is the rupture load $(\mathrm{N}), \mathrm{b}$ is the specimen thickness $(\mathrm{mm}), \mathrm{r}_{1}$ is the radius of the supporting circle $(\mathrm{mm}), \mathrm{r}_{2}$ is the radius of the loaded area $(\mathrm{mm}), \mathrm{r}_{3}$ is the sample radius $(\mathrm{mm})$ and $v$ is the measured Poisson's ratio equal to 0.31 . The statistical evaluation of flexural strength was carried-out using Weibull statistics [20,21]. Details of the accomplishment of this statistical analysis are presented in a previous study [2].

Finite element modeling (FEM): the numerical simulation of the biaxial flexural strength test was performed with the commercial finite element code Abaqus v.6.9 using the implicit static method. Assuming firstly linear isotropic elasticity described by means of Hooke's generalized law and then considering the geometrical symmetry of biaxial flexural strength test tooling, which was composed by a cylindrical piston and three supporting spherical balls $120^{\circ}$ apart, as well as the disc specimen geometry, a three-dimensional (3D) finite element model was assembled using one-third of the geometry as shown in Fig. 1. To reduce the CPU time, the cylindrical flat punch was replaced by a uniform pressure applied in the corresponding contact area with the disc as schematically depicted by the arrows in Fig. 1. The 3D biaxial flexural strength test model was defined by the following geometrical parameters: cylindrical flat punch radius $r_{p}=0.7 \mathrm{~mm}$, spherical ball radius $r_{b}=1.75 \mathrm{~mm}$, circle supporting ball radius $\mathrm{c}_{\mathrm{b}}=5.5 \mathrm{~mm}$ and disc specimen radius $\mathrm{r}_{\mathrm{d}}=7.95 \mathrm{~mm}$. To take into account the measured variations of the initial thickness of all tested discs, 3 finite element models were defined with uniform thick gauge as a function of the average thickness $\mathrm{t}_{\mathrm{d}}=1.34 \mathrm{~mm}$ and corresponding standard deviation of $\pm 0.03 \mathrm{~mm}$. Hereafter, the finite models are referred as P-3B_Min, P-3B_Med and P-3B_Max corresponding to the experimental measured average thickness $\left(t_{d}\right)$ of the tested disc specimens, respectively, $1.31 \mathrm{~mm}$ (minimum), $1.34 \mathrm{~mm}$ (medium) and $1.37 \mathrm{~mm}$ (maximum). The maximum pressure $\left(\mathrm{p}_{\max }, \mathrm{MPa}\right)$ values applied to the flat punch, resulting from the experimental disc fracture loading, were determined from the experimental average peak load considering its standard deviation $\overline{\mathrm{F}}_{\mathrm{p}}=1326.3 \pm 110.7 \mathrm{~N}$ and the flat cylindrical punch contact area $\mathrm{A}_{\mathrm{p}}\left(\mathrm{mm}^{2}\right)$ as:

$$
\mathrm{P}_{\max }=\frac{\overline{\mathrm{F}}_{\mathrm{p}}}{\mathrm{A}_{\mathrm{p}}}
$$

and, then, prescribed to the biaxial flexural finite element models P-3B_Min, P-3B_Med and P-3B_Max. Table I summarizes the experimental conditions of the biaxial flexural strength test evaluated by means of finite element simulations. The pressure loading was applied by means of a ramp amplitude load from zero to the maximum pressure values listed in Table I.

In the 3D finite element model, both disc and balls were described by linear reduced integration solid elements C3D8R according to Abaqus terminology. The finite element mesh shown in Fig. 1 was refined in the contact regions between the disc and the balls as well as in the uniform pressure area corresponding to the piston loading. It is worth to observe a mapped mesh of the disc composed by 57320 elements with 20 layers across the thickness and 6448 elements for each one-fourth sphere supporting ball in a total of 70216 elements for the proposed finite element model of the biaxial flexure strength test (P-3B). A local cylindrical coordinate $(\mathrm{O}, \mathrm{r}, \theta, \mathrm{z})$ system was defined with its origin at the bottom center of the disc. The boundary conditions imposed at the bottom surfaces of both one-fourth sphere supporting balls restricted the displacements along the radial (r), hoop $(\theta)$ and

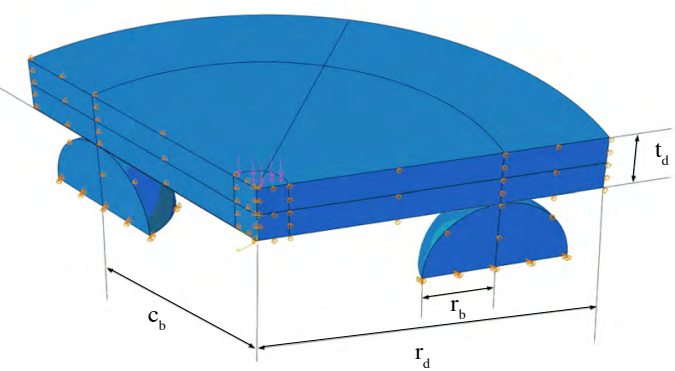

Figure 1: 3D solid model of the biaxial flexural strength (piston-onthree balls, P-3B) test.

[Figura 1: Modelo sólido 3D do teste de resistência à flexão biaxial (pistão em três bolas, $P$-3B).] 
Table I - Geometrical parameters and loading conditions adopted in the numerical simulations.

[Tabela I - Parâmetros geométricos e condições de carregamentos adotados nas simulações numéricas.]

\begin{tabular}{cccc}
\hline Model & $\begin{array}{c}\text { Disc thickness } \\
(\mathrm{mm})\end{array}$ & $\begin{array}{c}\text { Maximum } \\
\text { force } \\
(\mathrm{N})\end{array}$ & $\begin{array}{c}\text { Maximum } \\
\text { pressure } \\
(\mathrm{MPa})\end{array}$ \\
\hline P-3B_Min & 1.31 & 1215.55 & 790 \\
P-3B_Med & 1.34 & 1326.26 & 862 \\
P-3B_Max & 1.37 & 1436.97 & 934 \\
\hline
\end{tabular}

Note: disc diameter $=15.9 \mathrm{~mm}$ for all cases.

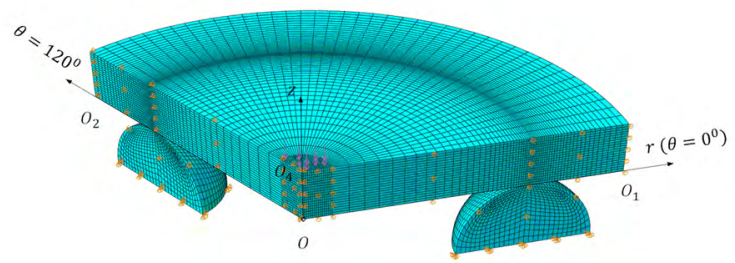

Figure 2: Finite element mesh and boundary conditions of the 3D model.

[Figura 2: Malha de elementos finitos e condições de contorno do modelo 3D.]

axial (z) directions. Symmetry boundary conditions of zero displacement along the hoop direction were defined for all the nodes of both disc and one-fourth sphere supporting balls which were located at the two symmetry planes: $\left(\mathrm{O}, \theta=0^{\circ}\right)$ and $\left(\mathrm{O}, \theta=120^{\circ}\right)$. In addition, the radial displacements of the disc nodes located at the centerline axis $(\mathrm{O}, \mathrm{z})$ were set equal to zero. To analyze the predictions of the stress components along the $(\mathrm{r}, \theta, \mathrm{z})$ directions, three node paths were defined at the bottom disc, as shown in Fig. 2, O- $\mathrm{O}_{1}\left(\theta=0^{\circ}\right), \mathrm{O}-\mathrm{O}_{2}$ $\left(\theta=120^{\circ}\right)$, and $\mathrm{O}-\mathrm{O}_{3}$ at the orientation $\theta=60^{\circ}$, which is not shown in the figure. An additional node path $\mathrm{O}_{-} \mathrm{O}_{4}$ was defined along the centerline axis of the disc.

Both Y-TZP dental ceramic and supporting ball spheres

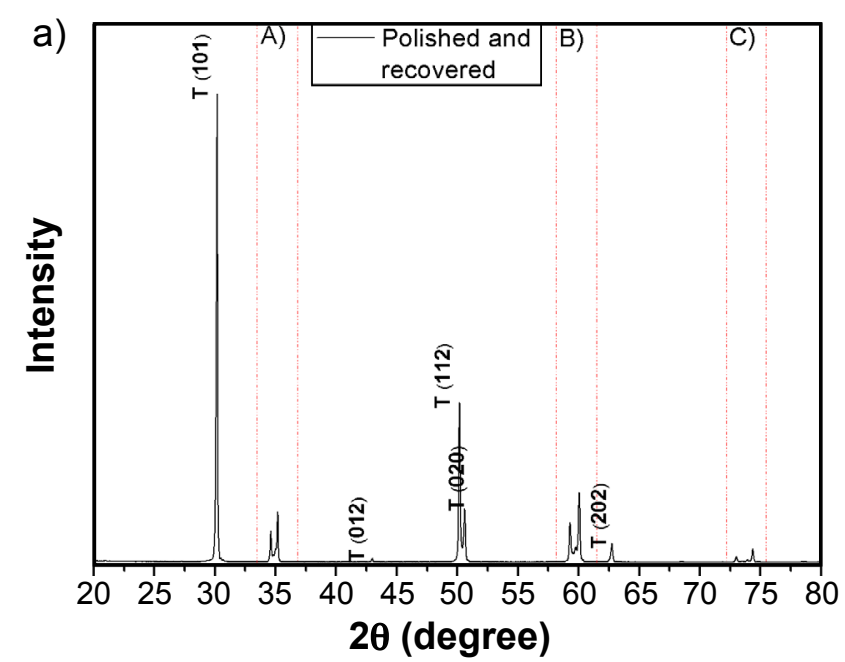

were considered as isotropic linear elastic materials defined by Hooke's generalized elasticity law. For the ball spheres, Young's modulus (E) and Poisson's ratio ( $v)$ were defined as $207000 \mathrm{MPa}$ and 0.29 , respectively. For the Y-TZP ceramic, Young's modulus and Poisson's ratio determined from IET test, as described above, were defined using the experimental average values, namely, $195300 \mathrm{MPa}$ and 0.31 , respectively. The contact between the bottom surface of the disc and the supporting ball spheres was described by a surfaceto-surface discretization method assuming a frictionless condition for the tangential behavior and a penalty method as a constraint enforcement method for the normal behavior. From finite element simulations of the P-3B test, Huang and Hsueh [22] verified that the friction effect is negligible when the disc is supported by three balls; they determined the critical value of the Coulomb friction coefficient obtained in the numerical study of the P-3B test as $\mu=0.15$, which, in turn, prevents the frictional contact between the disc and supporting balls. Bearing in mind the low average roughness of the disc surfaces evaluated in this study $(0.06 \mu \mathrm{m})$ and that a thin plastic film was placed between the disc and the flattened piston, preliminary simulations were performed with the P-3B_Med model specimen test geometry using either frictionless $(\mu=0)$ and critical non-slipping $(\mu=0.15)$ contact conditions. The corresponding numerical predictions of the disc stress distributions were insensitive to both friction conditions and, thus, a frictionless contact was assumed in all the P-3B biaxial flexure simulations. The finite element simulations were performed with the general static implicit solver of the Abaqus finite element code using the nonlinear option owing to the contact problem between the disc and the spheres. All the numerical simulations were run with a dualprocessor workstation Intel Xeon $56903.47 \mathrm{GHz}, 24$ cores with $32 \mathrm{~Gb}$ RAM.

\section{RESULTS AND DISCUSSION}

Sintered Y-TZP characterizations: Fig. 3 shows XRD

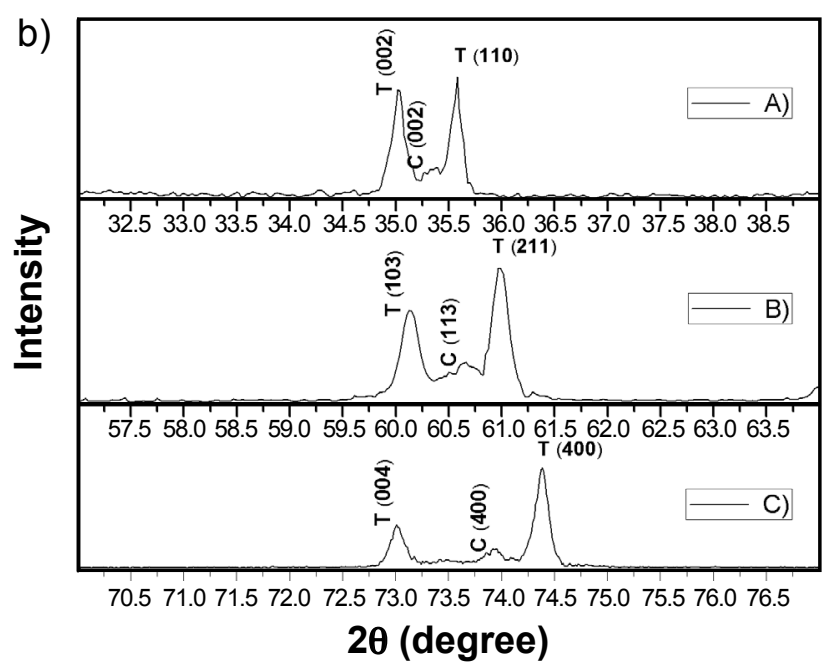

Figure 3: XRD pattern of Y-TZP sample (a) and pattern regions (b) showing the majority phases, $\mathrm{ZrO}_{2}$-tetragonal and $\mathrm{ZrO}_{2}$-cubic. [Figura 3: Padrão de DRX de amostra de Y-TZP (a) e regiões do padrão (b) mostrando as fases majoritárias, $\mathrm{ZrO}_{2}$-tetragonal e $\mathrm{ZrO}_{2}$-cúbica.] 
Table II - Results of Rietveld refinement of sintered Y-TZP (after polishing and heat-treatment at $1250{ }^{\circ} \mathrm{C} / 30 \mathrm{~min}$ ). [Tabela II - Resultados do refinamento de Rietveld de $Y$-TZP sinterizado (após polimento e tratamento térmico a $\left.1250{ }^{\circ} \mathrm{C} / 30 \mathrm{~min}\right)$.]

\begin{tabular}{|c|c|}
\hline Characteristic & Value \\
\hline $\begin{array}{c}\mathrm{ZrO}_{2} \text {-monoclinic (space group } \\
\mathrm{P} 121 / \mathrm{c} 1 \text { ) }\end{array}$ & Not found \\
\hline $\begin{array}{c}\mathrm{ZrO}_{2} \text {-tetragonal (space group } \\
\mathrm{P} 42 / \mathrm{nmc})\end{array}$ & $a=3.604 \AA ; c=5.178 \AA$ \\
\hline $\begin{array}{c}\mathrm{ZrO}_{2} \text {-cubic (space group } \\
\text { Fm } 3 \mathrm{~m})\end{array}$ & $a=5.131 \AA$ \\
\hline Composition (wt\%) & $\begin{array}{c}\text { 71.4\% } \mathrm{ZrO}_{2} \text {-tetragonal; } \\
28.6 \% \mathrm{ZrO}_{2} \text {-cubic }\end{array}$ \\
\hline $\begin{array}{c}\mathrm{Y}_{2} \mathrm{O}_{3} \text { content in tetragonal } \\
\text { phase }(\%)\end{array}$ & 2.40 \\
\hline$\chi^{2}$ & 2.89 \\
\hline
\end{tabular}

pattern of a sintered Y-TZP sample and Table II presents the results of Rietveld refinement. The crystalline phases presented in the sintered sample were $\mathrm{ZrO}_{2}$-tetragonal and $\mathrm{ZrO}_{2}$-cubic. The results of the Rietveld refinement performed on the surfaces of the sintered samples indicated $\mathrm{ZrO}_{2}$-tetragonal phase content close to $72 \%$ and $\mathrm{ZrO}_{2}$-cubic close to $28 \%$, with slight variations. This behavior was representative of tetragonal phase recovery during thermal treatment at $1250{ }^{\circ} \mathrm{C} / 2 \mathrm{~h}$, since $\mathrm{m} \rightarrow \mathrm{t}$ transformation occurs at $1170{ }^{\circ} \mathrm{C}$ under equilibrium conditions. Therefore, the final surface of the Y-TZP samples, obtained after polishing and subsequent thermal treatment, did not show any signs of monoclinic phase, maximizing $\mathrm{ZrO}_{2}$-tetragonal grains during P-3B flexural tests. According to Table II, the phase contents measured by the Rietveld refinement were very close to those obtained by the lever rule of approximately 71.4\% for $\mathrm{ZrO}_{2}$-tetragonal and $28.6 \%$ for $\mathrm{ZrO}_{2}$-cubic using the $\mathrm{ZrO}_{2}-\mathrm{Y}_{2} \mathrm{O}_{3}$ phase diagram. The measured $\mathrm{Y}_{2} \mathrm{O}_{3}$ content pointed to a structure of high tetragonality, indicating the presence of a transformable $\mathrm{ZrO}_{2}$ phase [15].
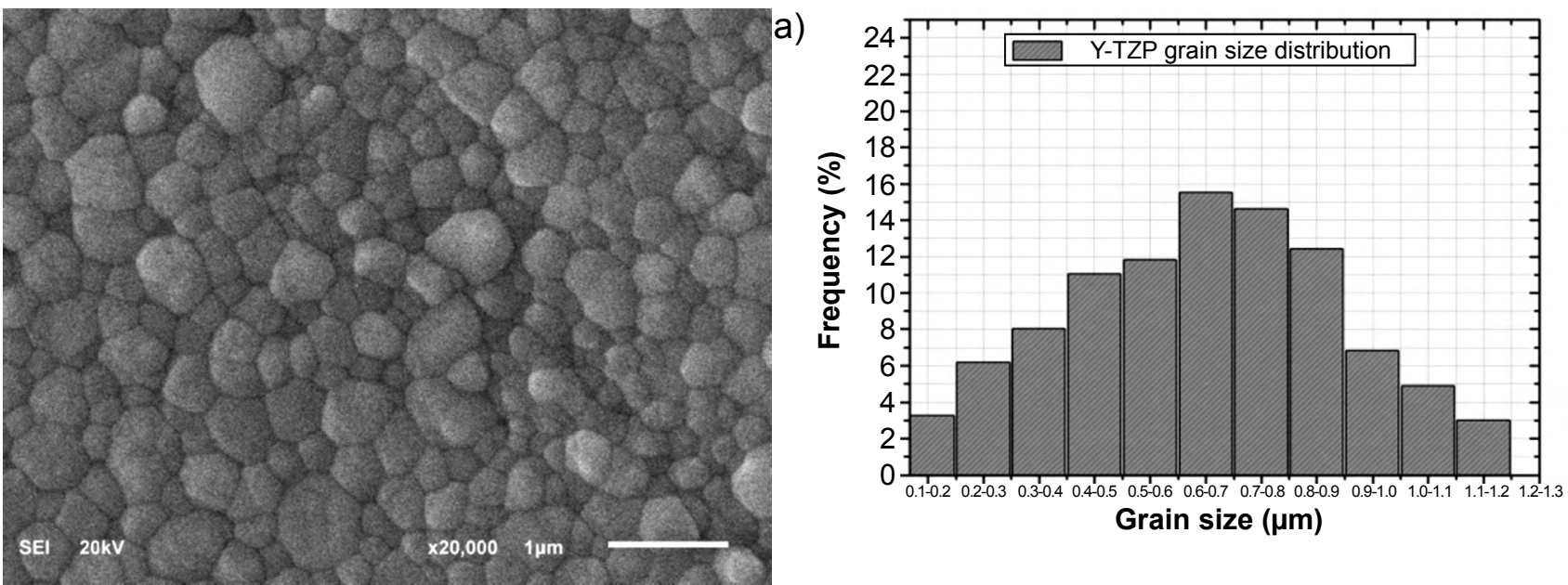

b)
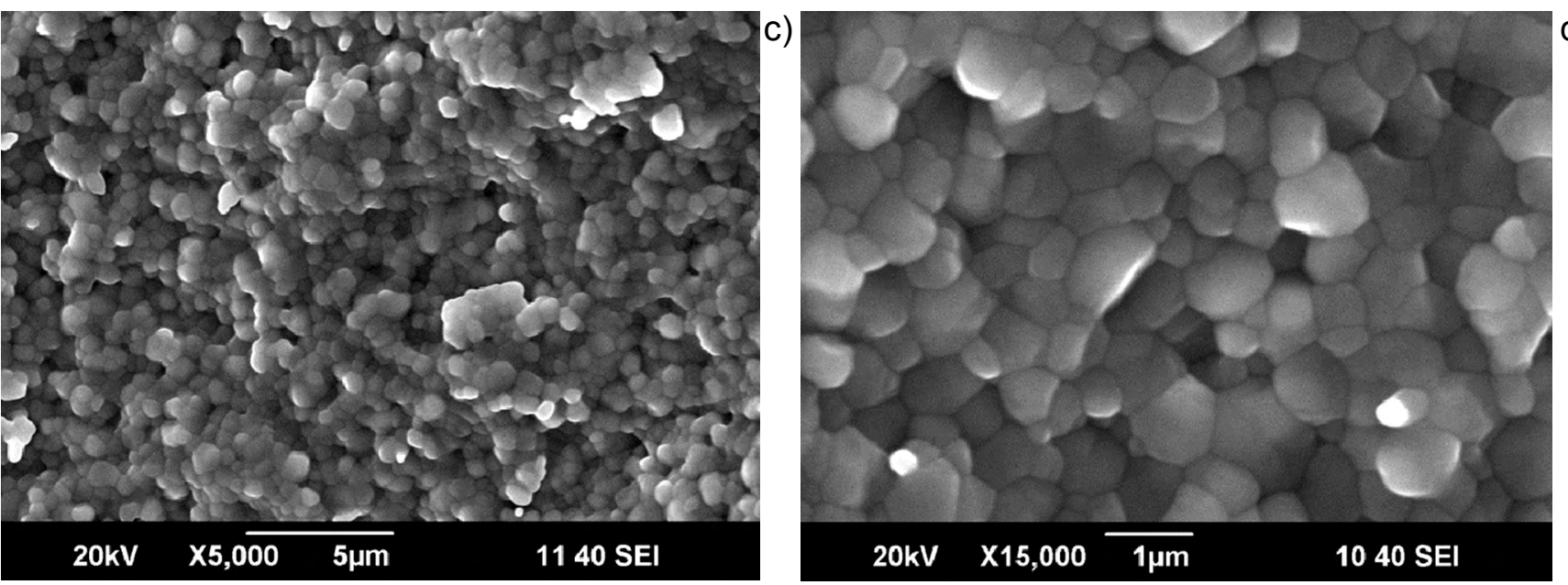

Figure 4: SEM micrographs of Y-TZP samples sintered at $1475{ }^{\circ} \mathrm{C} / 2 \mathrm{~h}$ : a) polished surface; b) quantification of grain size; c,d) fractured surface after piston-on-three balls (P-3B) test.

[Figura 4: Micrografias de amostras de Y-TZP sinterizadas a $1475^{\circ} \mathrm{C} / 2 \mathrm{~h}:$ a) superfície polida; $b$ ) quantificação do tamanho de grãos; c,d) superfície fraturada após teste de pistão em três bolas $(P-3 B)$.] 
Table III - Properties of Y-TZP sintered specimens $\left(1475{ }^{\circ} \mathrm{C} / 2 \mathrm{~h}\right)$.

[Tabela III - Propriedades das amostras de Y-TZP sinterizadas a $1475^{\circ} \mathrm{C} / 2 \mathrm{~h}$ ).]

\begin{tabular}{ccccccccc}
\hline $\begin{array}{c}\text { Relative } \\
\text { density } \\
(\%)\end{array}$ & $\begin{array}{c}\text { Roughness, } \mathrm{R}_{\mathrm{a}} \\
(\mu \mathrm{m})\end{array}$ & $\begin{array}{c}\text { Hardness, } \\
\mathrm{HV}_{\text {1000g }}\end{array}$ & $\begin{array}{c}\text { Fracture } \\
\text { toughnes } \\
\left(\mathrm{MPa}^{1 / 2}\right)\end{array}$ & $\begin{array}{c}\text { Poisson's } \\
\text { ratio }\end{array}$ & $\begin{array}{c}\text { Young's } \\
\text { modulus } \\
(\mathrm{GPa})\end{array}$ & $\begin{array}{c}\text { Flexural } \\
\text { strength P-3B } \\
(\mathrm{MPa})\end{array}$ & $\begin{array}{c}\text { Characteristic } \\
\text { strength } \\
(\mathrm{MPa})\end{array}$ & $\begin{array}{c}\text { Weibull } \\
\text { modulus, } \\
\mathrm{m}\end{array}$ \\
\hline $99.8 \pm 0.2$ & $0.058 \pm 0.011$ & $1254 \pm 23$ & $7.2 \pm 0.5$ & 0.31 & $195.3 \pm 4.2$ & $1191 \pm 9$ & 1285.5 & 16.3 \\
\hline
\end{tabular}

Fig. 4 shows representative SEM micrographs of sintered Y-TZP and Table III presents the characteristics of Y-TZP sintered samples. The results depicted in Figs. 3 and 4 indicated that the sintered samples presented both $\mathrm{ZrO}_{2}$-tetragonal and $\mathrm{ZrO}_{2}$-cubic as crystalline phases. Microstructural analysis indicated equiaxial $\mathrm{ZrO}_{2}$ grains with an average size of about $0.63 \pm 0.24 \mu \mathrm{m}$, with monomodal distribution and maximum variation between 0.15 and $1.2 \mu \mathrm{m}$. No conclusive differences in grain morphology between $\mathrm{ZrO}_{2}$-tetragonal and $\mathrm{ZrO}_{2}$-cubic were observed in this study. The ceramic samples presented relative density of $99.8 \% \pm 0.2 \%$ (Table III) showing that, during the sintering at $1475{ }^{\circ} \mathrm{C} / 2 \mathrm{~h}$, complete densification of Y-TZP samples occurred. The low standard deviation of grain size $(0.2 \mu \mathrm{m})$, associated with the presented SEM micrographs, allowed to consider that the material had only residual porosity, in nanometric or submicrometric scale, homogeneously distributed along the grain boundaries of ceramic samples. Vickers hardness of around $1254 \pm 29 \mathrm{HV}$, fracture toughness of $7.2 \pm 0.5 \mathrm{MPa} \cdot \mathrm{m}^{1 / 2}$ and Young's modulus of $195 \pm 4 \mathrm{GPa}$, values frequently found in the literature [23-25], indicated the good homogeneity of the material used in this study.

The results of flexural strength obtained from P-3B test showed average values of $1191 \pm 9 \mathrm{MPa}$ in samples whose tensile surface (polished) present average roughness $\mathrm{R}_{\mathrm{a}}$ of $0.058 \pm 0.011 \mu \mathrm{m}$. Fig. 5 presents Weibull plot, failure probability according to the flexural strength of sintered Y-TZP samples sintered at $1475{ }^{\circ} \mathrm{C} / 2 \mathrm{~h}$. It was observed that the group of tested samples presented characteristic strength $\left(\sigma_{0}\right)$ of $1285 \mathrm{MPa}$, representing $63.2 \%$ of failure
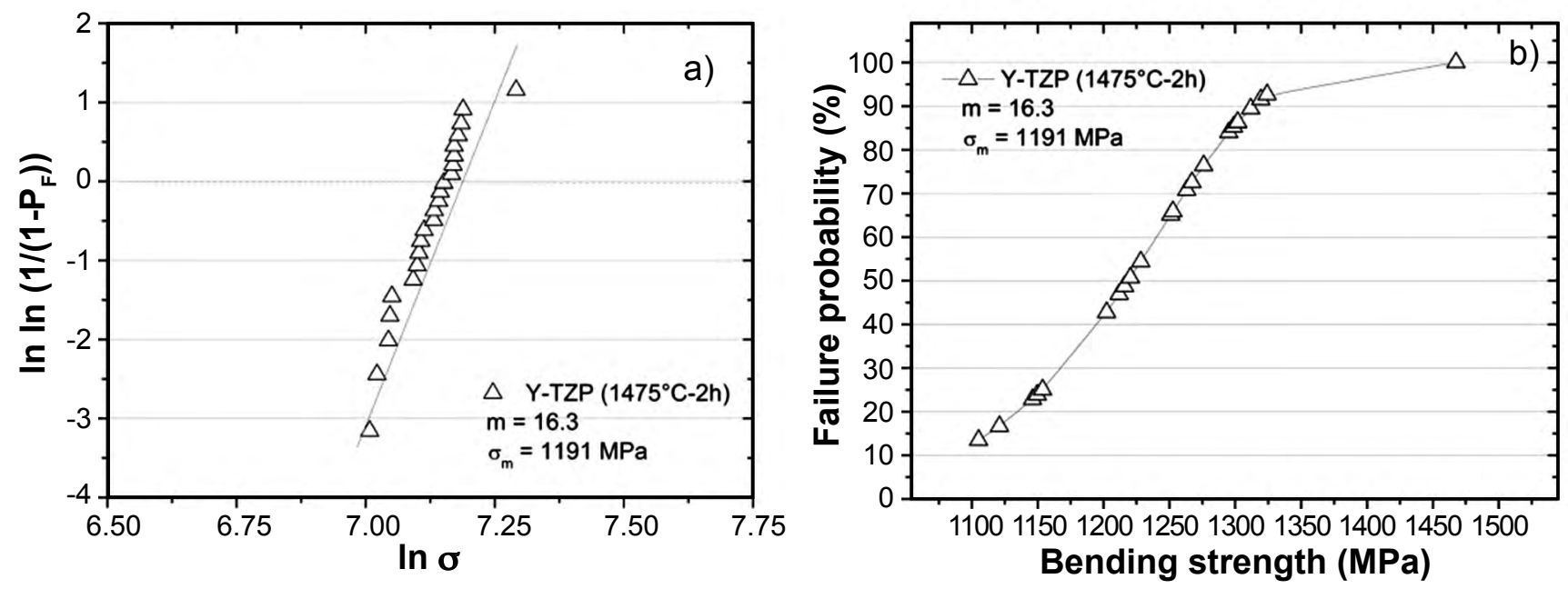

Figure 5: Weibull plot (a) and curve of failure probability (b) for the flexural strength of sintered Y-TZP samples.

[Figura 5: Gráfico de Weibull (a) e curva de probabilidade de falha (b) da resistência à flexão de amostras sinterizadas de Y-TZP.]
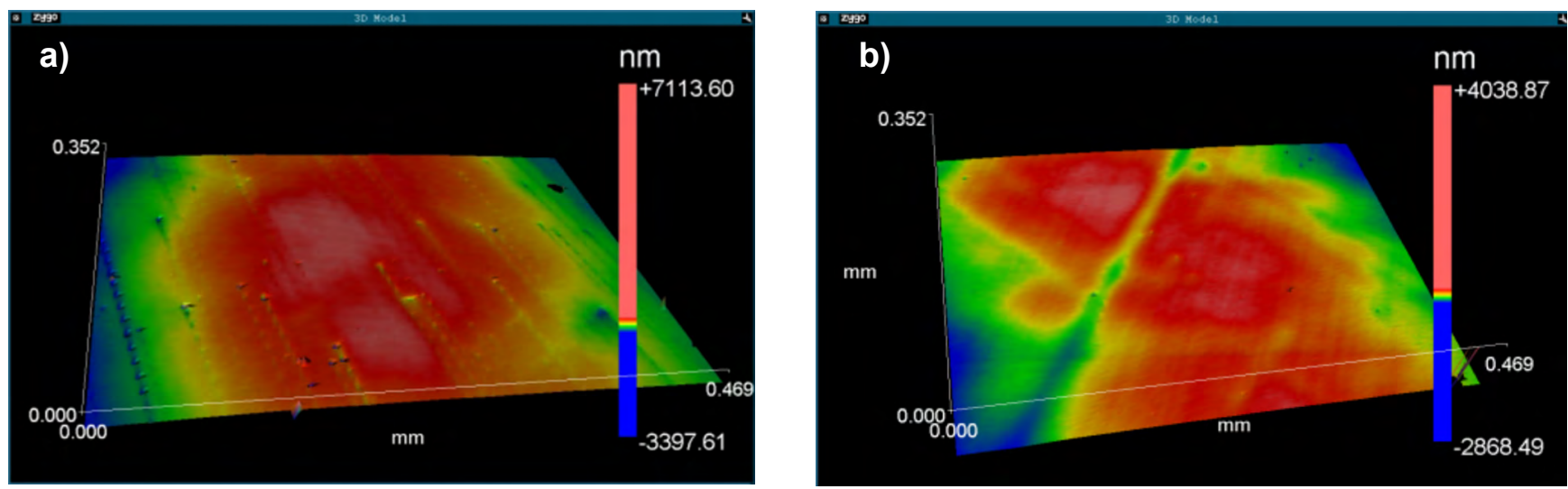

Figure 6: 3D profiles of polished Y-TZP specimens broken at the (a) lowest (1100 MPa) and (b) highest (1430 MPa) fracture stress in the group. [Figura 6: Perfis 3D de amostras polidas de Y-TZP rompidas na (a) menor (1100 MPa) e (b) maior (1430 MPa) tensão de fratura no grupo.] 
probability. The range of modulus of rupture in the tested group $(n=23)$ presented values between 1105 and $1467 \mathrm{MPa}$, which indicated that the group of tested samples presented good reproducibility. The high Weibull modulus presented by the material, $\mathrm{m}=16.3$, confirmed the homogeneity of the Y-TZP studied. This feature is especially necessary for dentistry purposes, since it indicates the reliability of the material in critical applications such as dental prostheses. As previously mentioned, the surface roughness result obtained by $3 \mathrm{D}$ interferometer indicated low average roughness $\left(\mathrm{R}_{\mathrm{a}}\right)$ of $0.06 \pm 0.01 \mu \mathrm{m}$. Fig. 6 presents representative roughness maps of the samples broken at the highest and lowest fracture stresses, showing that the surfaces presented a high polishing degree, minimizing the roughness effects on the results of biaxial flexure strength of the evaluated Y-TZP ceramic.

Finite element predictions: the numerical predictions obtained with the proposed 3D finite element model of the piston-on-three-ball testing (biaxial flexural strength) of the Y-TZP dental ceramics are discussed in this section. Recalling that three finite element models were defined to describe the experimentally tested average initial disc thickness, viz.,P-3B_Min $(1.31 \mathrm{~mm})$, P-3B_Med $(1.34 \mathrm{~mm})$ and P-3B_Max $(1.37 \mathrm{~mm})$. The predicted stress values at the bottom surface along the radial (S11) and hoop (S22) directions are presented in Fig. 7 as contour plots obtained from the deformed threefold symmetry 3D finite element model, which is displayed as a full disc geometry created from a circular pattern using the local cylindrical coordinate system. From Fig. 7 it is possible to observe first that an almost equibiaxial stress state was achieved at the center of the bottom of the disc. From the centroid of the first 3D solid element at the disc center, the radial (S11) and hoop (S22) stress values were, respectively, 1119.35 and $1117.54 \mathrm{MPa}$ for P-3B_Min, 1163.91 and 1161.45 MPa for P-3B_Med, and 1202.94 and $1199.80 \mathrm{MPa}$ for P-3B_Max. Secondly, the biaxial tensile strength in the disc increased with the ratio between the experimentally measured maximum piston force and the square of the initial disc thickness $\left(\mathrm{F}_{\max } / \mathrm{t}^{2}\right.$, see the measured values in Table I), as verified in a parametric study conducted in [9]. In our study, the experimental values of $\mathrm{F}_{\max } / \mathrm{t}^{2}$ were $708.32,738.62$ and $765.61 \mathrm{MPa}$ for the finite element models P-3B_Min $(1.31 \mathrm{~mm})$, P-3B_Med $(1.34 \mathrm{~mm})$ and P-3B_Max $(1.37 \mathrm{~mm})$, respectively. As expected, higher compressive stresses were obtained in the contact areas of the disc bottom surfaces with the supporting spherical balls. From the contour plots depicted in Fig. 7, it is worth to observe that the compressive stress level in the vicinity of the supporting contact zones increased with the ratio $\mathrm{F}_{\max } / \mathrm{t}^{2}$. Supporting balls with small radii produce tensile stresses (Hertz contact problem) in the vicinity of the contact area, which may be as higher as the tensile stress level at the disc center [9]. In that case, the onset of the fracture is expected to take place from the contact areas between the disc and the supporting spherical balls. In the present evaluated test geometry, such tensile contact stresses were not observed. Also, most of the fracture patterns in the
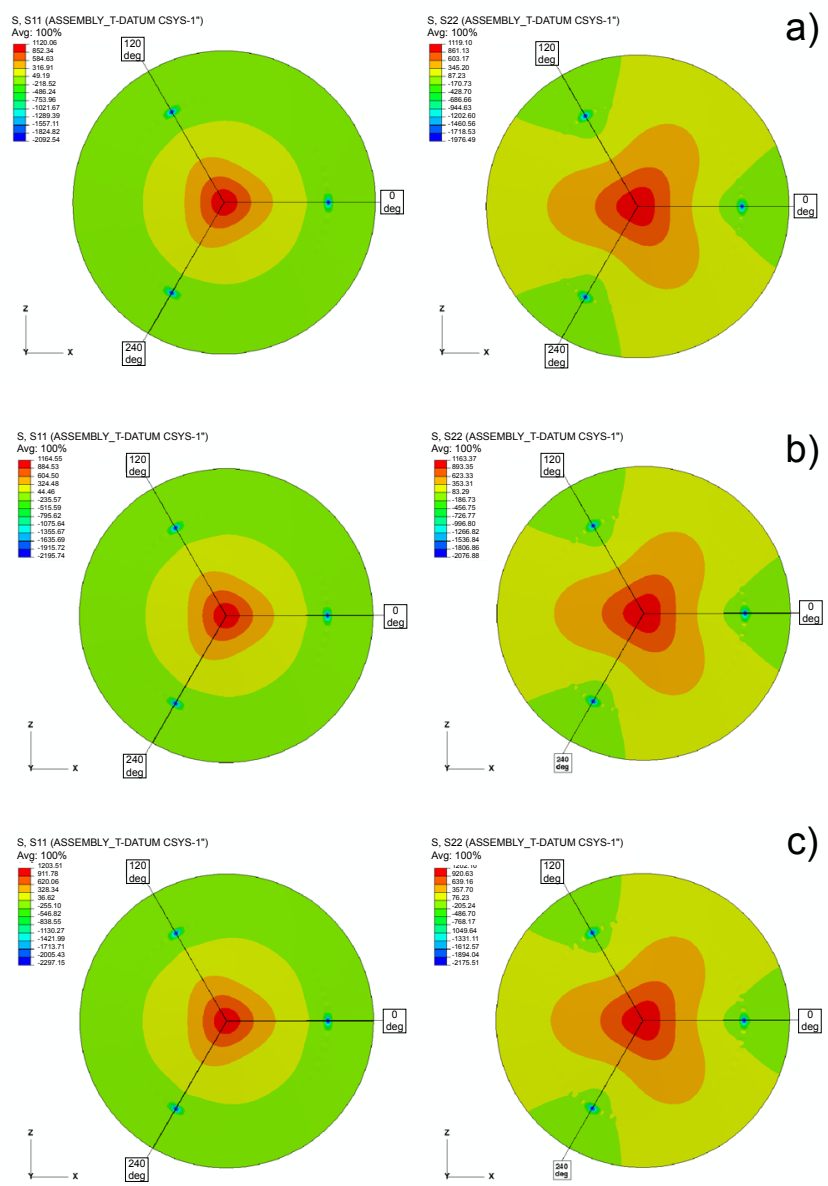

Figure 7: Radial (S11) and hoop (S22) stress contour plots at the disc bottom surface predicted by the finite element modeling of the biaxial flexural strength test of the Y-TZP: a) P-3B_Min (1.31 $\mathrm{mm})$; b) P-3B_Med (1.34 mm); and c) P-3B_Max (1.37 mm).

[Figura 7: Gráficos de contorno de tensão radial(S11) e tangencial (S22) na superfície inferior do disco previstos pela modelagem por elementos finitos do teste de resistência à flexão biaxial do Y-TZP: a) $P$-3B_Min $(1,31 \mathrm{~mm})$; b) $P$-3B_Med $(1,34 \mathrm{~mm})$; e c) $P$-3B_Max $(1,37 \mathrm{~mm})$.

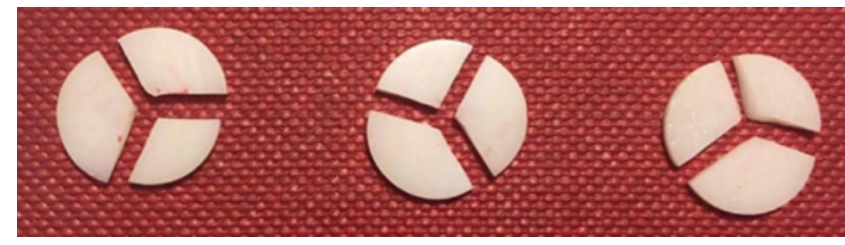

Figure 8: Fracture patterns of the sintered Y-TZP ceramic discs. [Figura 8: Padrões de fratura dos discos cerâmicos sinterizados de Y-TZP.]

tested discs of Y-TZP occurred along the threefold symmetry axes, as shown in Fig. 8. However, fractography analysis must be performed to verify whether the fracture started at the disc center or not.

The radial (S11) and hoop (S22) stress profiles along the paths $\mathrm{O}-\mathrm{O}_{1}\left(\theta=0^{\circ}\right)$ and $\mathrm{O}-\mathrm{O}_{3}\left(\theta=60^{\circ}\right)$ defined in the bottom disc surface, schematically shown in Fig. 7, are plotted in Fig. 9 as a function of the normalized radial distance from the center $\left(\mathrm{r} / \mathrm{r}_{\mathrm{d}}\right)$. Owing to the threefold symmetry, the results along the path $\mathrm{O}-\mathrm{O}_{2}\left(\theta=120^{\circ}\right)$ were equal to the values 

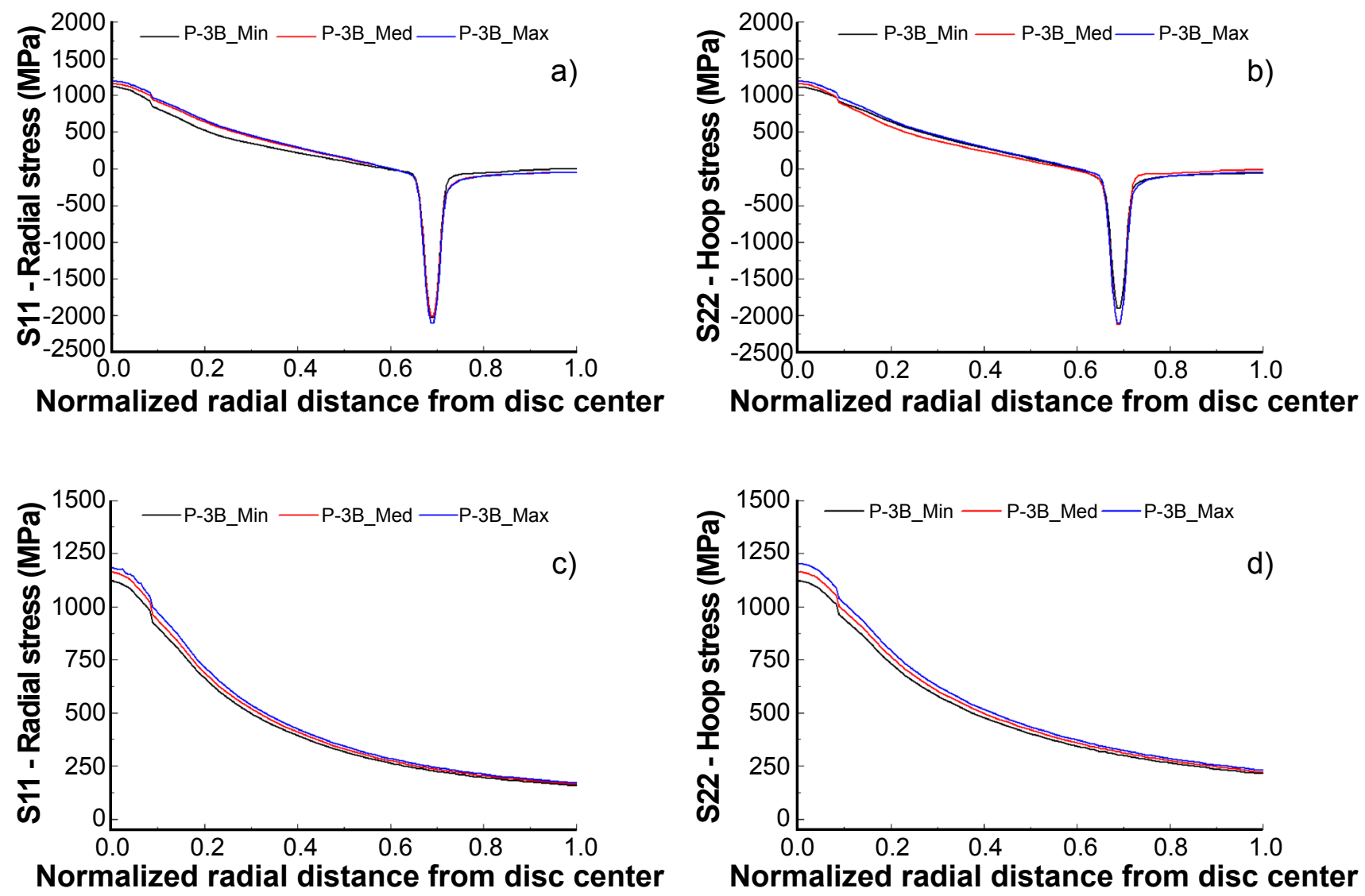

Figure 9: Radial (S11) and hoop (S22) stress components at the disc bottom surface predicted by the finite element modeling of the biaxial flexural test of the Y-TZP along the path: a,b) $\mathrm{O}-\mathrm{O}_{1}\left(\theta=0^{\circ}\right)$; and c,d) $\mathrm{O}-\mathrm{O}_{3}\left(\theta=60^{\circ}\right)$.

[Figura 9: Componentes de tensão radial (S11) e tangencial (S22) na superfície inferior do disco previstos pela modelagem de elementos finitos do teste de flexão biaxial do Y-TZP ao longo do caminho: a,b) $O-O_{1}\left(\theta=0^{\circ}\right)$; e c,d) $O-O_{3}\left(\theta=60^{\circ}\right)$.]

determined for the path $\mathrm{O}-\mathrm{O}_{1}\left(\theta=0^{\circ}\right)$ and, henceforth, are not discussed. The stress values in the radial and hoop directions were very close within a very small zone, namely, comprised between the disc center and $r / r_{d} \sim 0.1$ along the axes of the threefold symmetry and close to the disc center for the angular orientation $\theta=60^{\circ}$ (path $\mathrm{O}-\mathrm{O}_{3}$ ). In the unsupported regions of the disc bottom surface between $r / r_{d} \sim 0.1$ and $\sim 0.6$, both radial and hoop stresses can be viewed as the lower and upper bounds, respectively, of the corresponding radial and hoop stress components along the supported directions. In the contact region between the bottom disc and the supporting spherical balls, that is, at a normalized radial distance $\mathrm{r} / \mathrm{r}_{\mathrm{d}} \sim 0.7$ along $\mathrm{O}-\mathrm{O}_{1}\left(\theta=0^{\circ}\right)$ path in Fig. 9a, both radial and hoop components were compressive stresses. In the final disc region between the ball-disc contact area and the edge, the radial and hoop stresses along $\mathrm{O}-\mathrm{O}_{1}\left(\theta=0^{\circ}\right)$ path were close to zero. Conversely, along the path $\mathrm{O}-\mathrm{O}_{3}$ $\left(\theta=60^{\circ}\right)$ the radial stress component was positive (tensile) and decreased close to zero in the zone $0.7<\mathrm{r} / \mathrm{r}_{\mathrm{d}}<1$ (Fig. 9b), while the stress in the hoop direction along this path was also positive and higher than the radial component decreasing to a nonzero value at the disc edge.

The predicted axial (S33) and von Mises (SEQ) stress distributions along the paths $\mathrm{O}-\mathrm{O}_{1}\left(\theta=0^{\circ}\right)$ and $\mathrm{O}-\mathrm{O}_{3}\left(\theta=60^{\circ}\right)$ are plotted in Fig. 10. A very small axial compressive stress in the region near to the disc center, that is, $0<\mathrm{r} / \mathrm{r}_{\mathrm{d}}<0.2$, was observed along the angular orientation $\theta=60^{\circ}$ and was also displayed along the path $\mathrm{O}-\mathrm{O}_{1}\left(\theta=0^{\circ}\right)$, which, in fact, was too small to be seen in the plot owing to the larger compression stresses around the supporting contact zone. In the unsupported regions of the disc bottom surface, the axial compressive stresses were close to zero for normalized radial distances $r / r_{d}>0.2$ and, thus, these zones can be viewed as free surface regions under a near plane-stress state. The effective stress measure defined in the sense of the isotropic von Mises yield criterion, which, in fact, is cast from the principle of the maximum elastic strain distortion energy, can be useful to analyze the biaxial strength determined with the piston-on-three-ball test. The multiaxial nature of the stress states found in the disc regions under the action of the piston and contact related zones influenced the biaxial strength of the material and, therefore, can be explained as a function of the scalar measure of the von Mises stress. From Fig. 10, the von Mises effective stress values determined at the disc center were 1121.98, 1166.54 and $1205.54 \mathrm{MPa}$ for the models P-3B_Min $(1.31 \mathrm{~mm})$, P-3B_Med $(1.34 \mathrm{~mm})$ and P-3B_Max $(1.37 \mathrm{~mm})$, respectively. Bearing in mind that the proposed finite element models reflect the ensemble of the experimentally tested discs of Y-TZP dental ceramics, the corresponding average maximum von Mises stress at 
the disc center was $1164.69 \mathrm{MPa}$. The corresponding von Mises stress distributions along the paths defined at the two angular orientations $\left(\theta=0^{\circ}\right.$ and $\left.60^{\circ}\right)$ also resumed the expected stress states with increasing levels of the effective von Mises stress with the experimental values of the ratio $\mathrm{F}_{\max } / \mathrm{t}^{2}$. In this way, the scalar invariant measure of the von Mises effective stress may provide a first estimate for the biaxial strength of the Y-TZP ceramic obtained with the piston-on-three-ball test.

The analysis of the stress distributions in the disc was completed by plotting the components along the centerline axis (path $\mathrm{O}-\mathrm{O}_{4}$ across the disc thickness). Radial, hoop, axial and von Mises stress values along the path $\mathrm{O}_{-} \mathrm{O}_{4}$ are shown in Fig. 11 as a function of the normalized axial distance from the bottom surface disc center $\left(\mathrm{a} / \mathrm{t}_{\mathrm{d}}\right)$. Owing to the symmetry, radial and hoop stress components were equal along the path $\mathrm{O}_{-} \mathrm{O}_{4}$ and positive (tensile) and negative (compressive) at the bottom $\left(\mathrm{a} / \mathrm{t}_{\mathrm{d}}=0\right)$ and top $\left(\mathrm{a} / \mathrm{t}_{\mathrm{d}}=1\right)$ surfaces, respectively. Close to the half-thickness $\left(\mathrm{a} / \mathrm{t}_{\mathrm{d}}=0.5\right)$, both radial and hoop stresses were very small. From the distribution of the axial stress (S33) component, it is worth to observe that an almost equibiaxial tensile stress state was produced at the center of the bottom disc surface zone where the piston imposed a loading close to pure bending. The von Mises (SEQ) stress distribution along the centerline path was influenced by the magnitude of the compressive axial stress (S33) as the normalized distance $\mathrm{a} / \mathrm{t}_{\mathrm{d}}$ increased.

To summarize the stress analysis of the Y-TZP ceramics submitted to the biaxial flexural strength test, the contour plots of the maximum principal stress (S1) and the von Mises (SEQ) effective stress at the disc bottom surface are depicted in Fig. 12. From these plots, it is useful to observe first that the maximum principal stress contours were comparable to the hoop stress (S22) plots, indicating that this component was close to the maximum principal stress direction and that the disc fracture pattern might be initiated at the disc center and propagated in the radial direction towards the disc free edge.

Comparison between experimental results and finite element predictions of Y-TZP: polycrystalline ceramic materials usually present elastic behavior according to Hooke's law and, in general, its brittle failure is described by the Griffith criterium [26]. In zirconia ceramics, like the ones studied in this work (3Y-TZP), there is a peculiar component linked to its high toughness and bending strength, which can be explained by the toughening mechanisms of this ceramic. The three main theories proposed to explain the toughening mechanisms in zirconia are: 1) toughening by
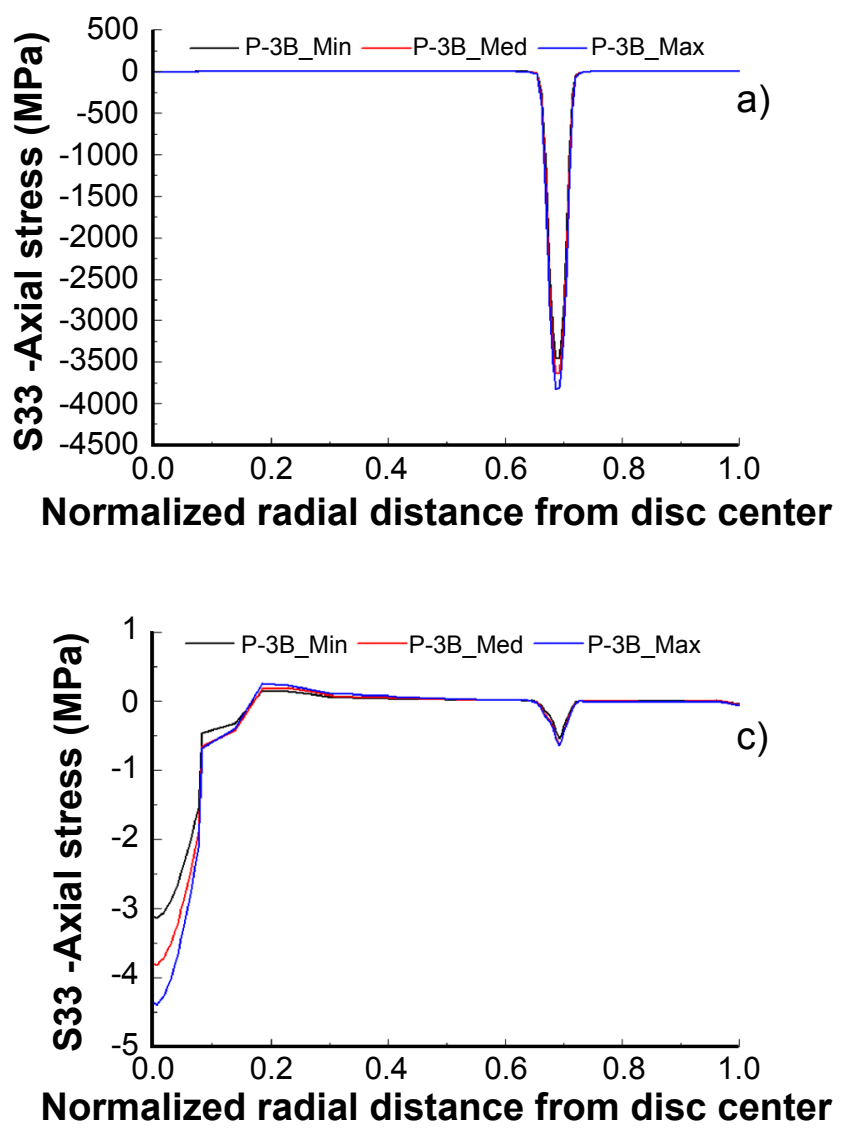
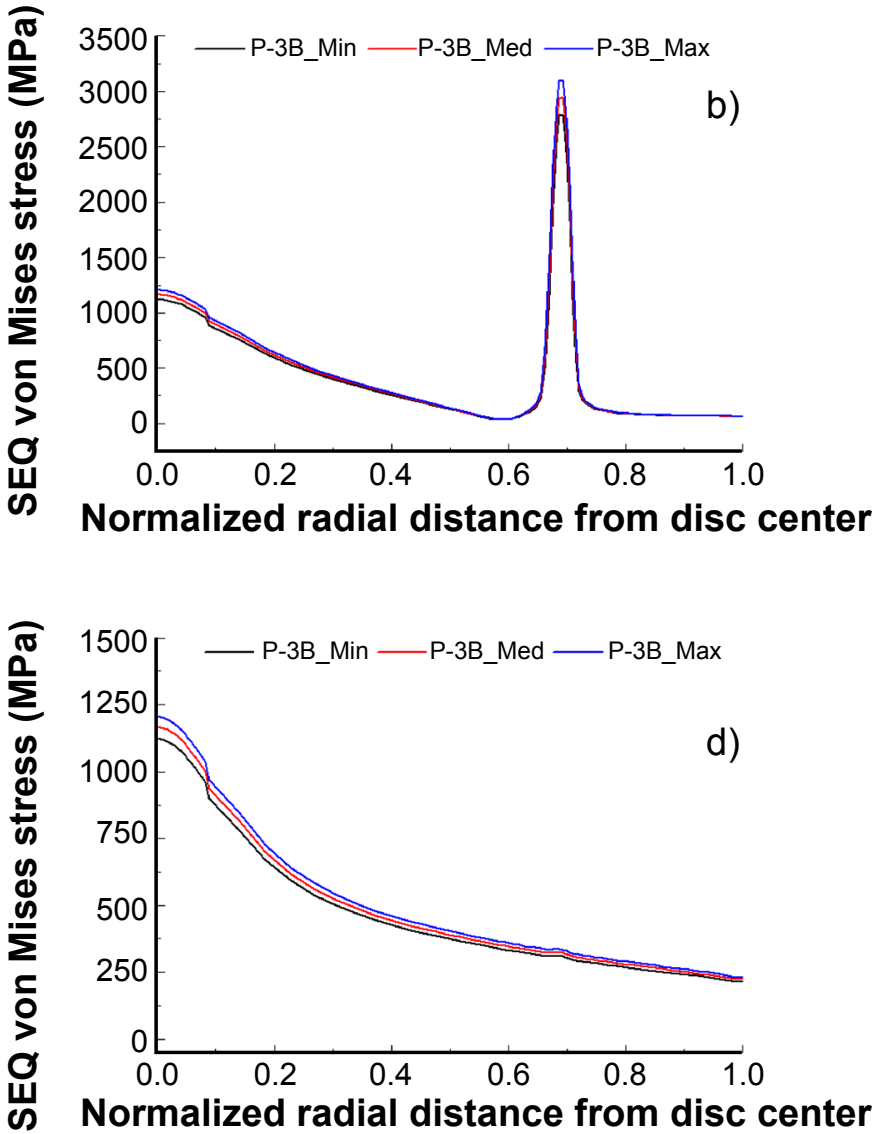

Figure 10: Axial (S33) and von Mises (SEQ) stress values at the disc bottom surface predicted by the finite element modeling of the biaxial flexural test of the Y-TZP along the path: a,b) $\mathrm{O}-\mathrm{O}_{1}\left(\theta=0^{\circ}\right)$; and c,d) $\mathrm{O}-\mathrm{O}_{3}\left(\theta=60^{\circ}\right)$.

[Figura 10: Valores de tensão axial (S33) e de von Mises (SEQ) na superfície inferior do disco prevista pela modelagem por elementos finitos do teste de flexão biaxial do Y-TZP ao longo do caminho: a,b) $O-O_{1}\left(\theta=0^{\circ}\right)$; e c,d) $O-O_{3}\left(\theta=60^{\circ}\right)$.] 

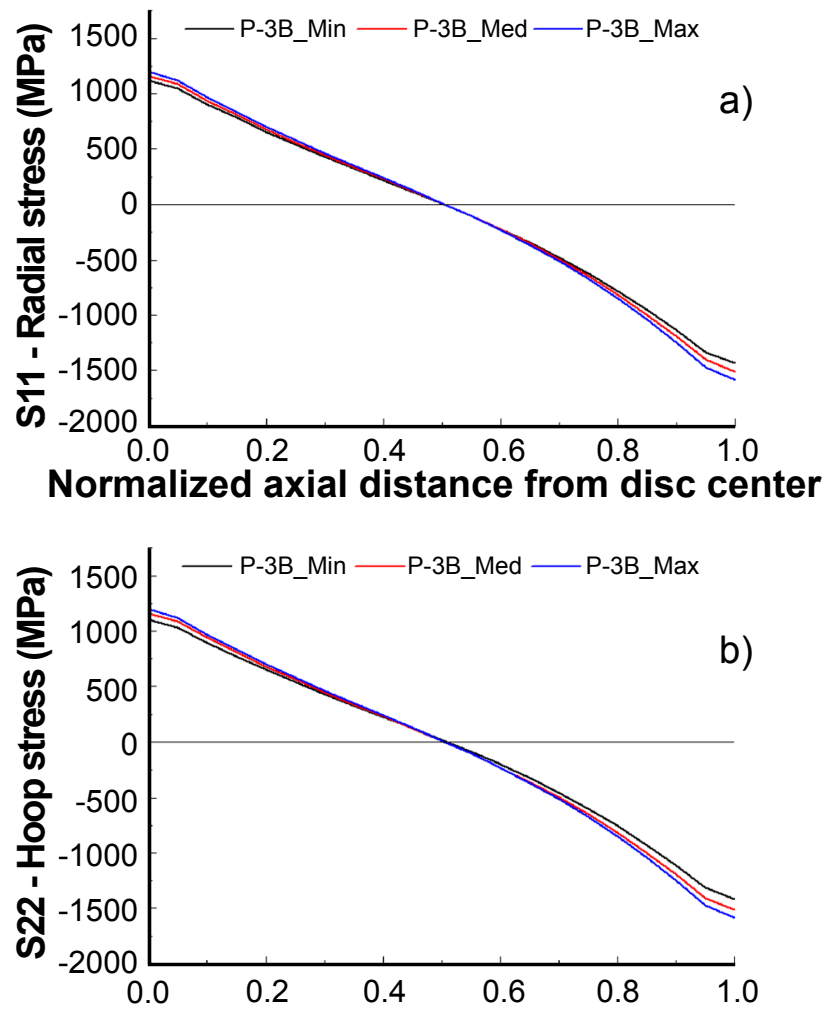

Normalized axial distance from disc center

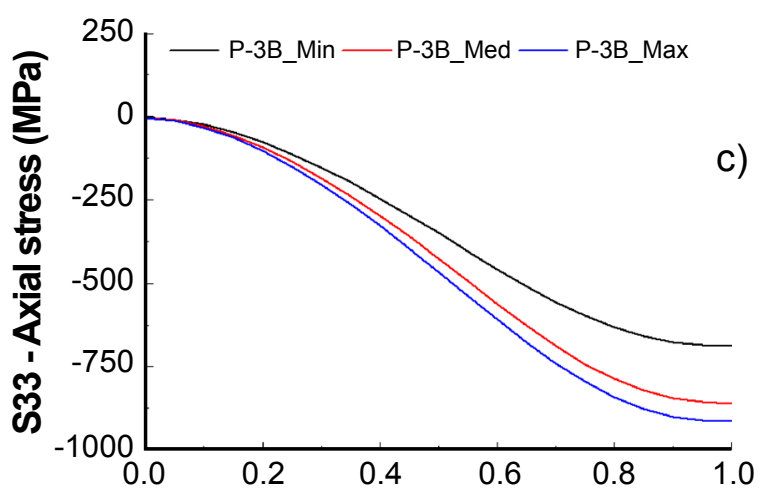

Normalized axial distance from disc center

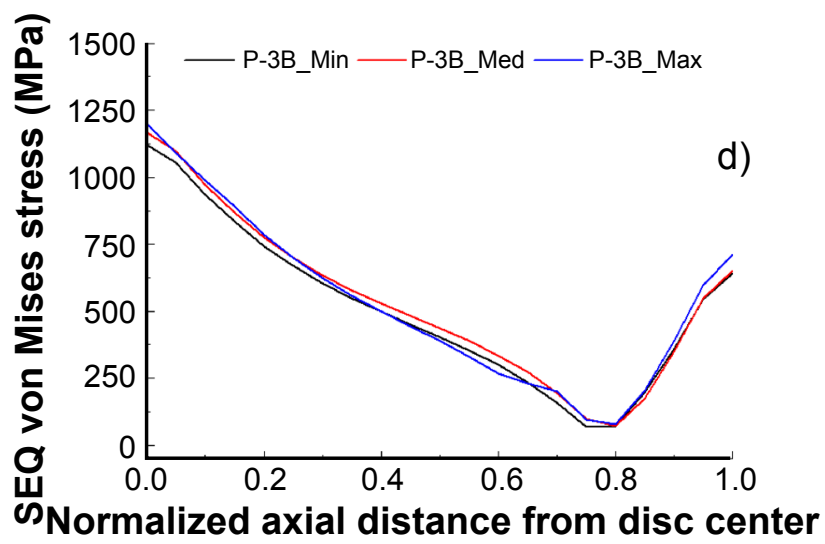

Figure 11: Predicted values of the radial S11 (a), hoop S22 (b), axial S33 (c), and von Mises SEQ (d) stress components along the disc centerline axis (path $\mathrm{O}-\mathrm{O}_{4}$ ).

[Figura 11: Valores previstos dos componentes de tensão radial S11 (a), tangencial S22 (b), axial S33 (c) e de von Mises SEQ (d) ao longo do eixo da linha central do disco (caminho $\mathrm{O}-\mathrm{O}_{4}$ ).]
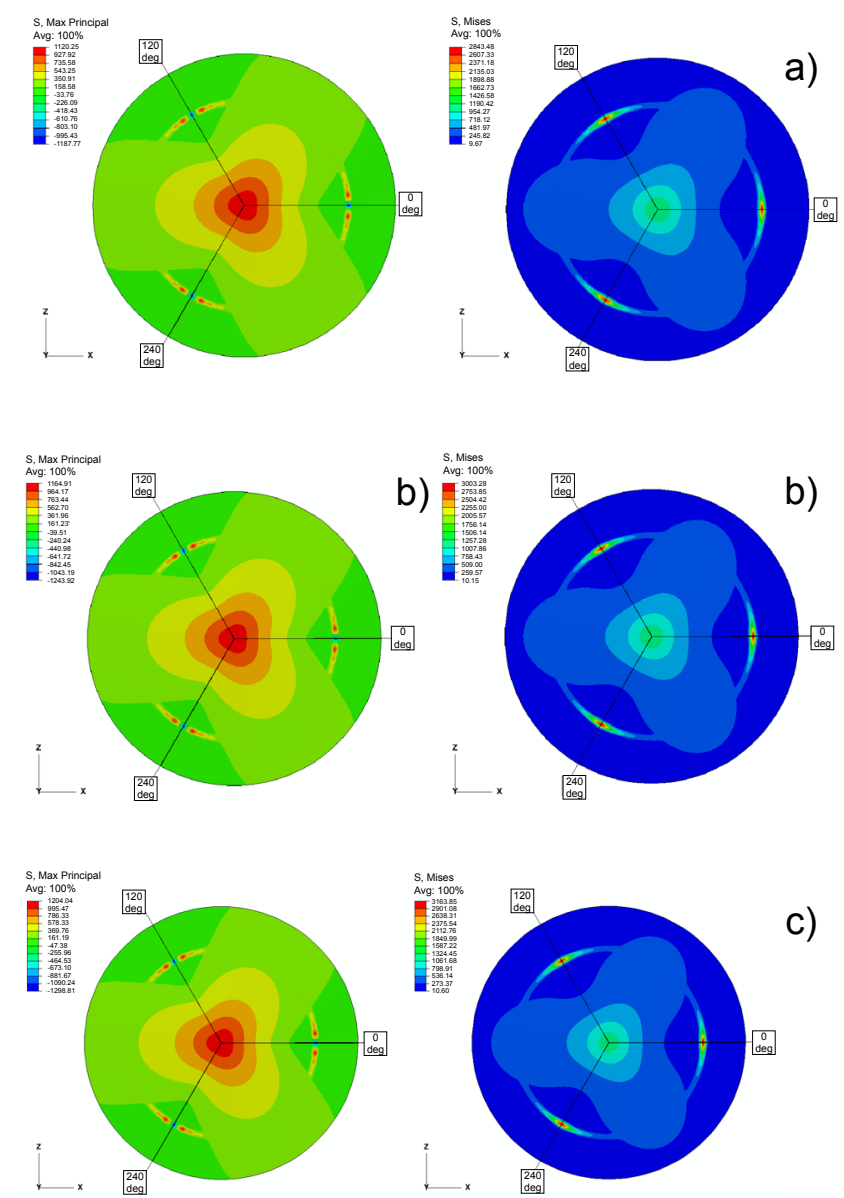

Figure 12: Maximum principal and von Mises stress contours at the disc bottom surface predicted by the finite element modeling of the biaxial flexural test of the Y-TZP: a) P-3B_Min $(1.31 \mathrm{~mm})$; b) P-3B_Med (1.34 mm); and c) P-3B_Max (1.37 mm).

[Figura 12: Contornos de tensão principal máxima e de von Mises na superfície inferior do disco previstos pela modelagem por elementos finitos do teste de flexão biaxial da Y-TZP: a) P-3B_Min $(1,31 \mathrm{~mm})$; b) P-3B_Med $(1,34 \mathrm{~mm})$; e c) P-3B_Max $(1,37 \mathrm{~mm})$.

transformation, via tetragonal transformation to monoclinic $(t \rightarrow m)$ [27-29]: in this theory, during the intergranular crack propagation, the aperture of this crack leads to compressive stresses on the surrounding $\mathrm{ZrO}_{2}$-tetragonal metastable grains; when it reaches a critical stress value, this tetragonal phase becomes monoclinic phase and, with the atomic rearrangement of the $\mathrm{ZrO}_{2}$ structure, during the solid-state $\mathrm{t} \rightarrow \mathrm{m}$ transformation, the newly transformed monoclinic grains present an volumetric expansion ratio of about $4-5 \%$; thus, the propagating crack is compressed towards the opposite direction of its opening, and extra stress is necessary for the continuity of its propagation; 2) a second strongly supported theory is the microcrack shielding [28-29]; this mechanism is a consequence of volumetric expansion and shear stress components associated with $\mathrm{t} \rightarrow \mathrm{m}$ transformation, which led to microcracking; thus, these two mechanisms are considered to be associated, promoting the toughening of yttrium-stabilized tetragonal $\mathrm{ZrO}_{2}(\mathrm{Y}-\mathrm{TZP})$; and 3) a third mechanism called ferroelastic domain 
Table IV - Comparisons between numerical predictions and experimental values of the 3Y-TZP biaxial flexure strength. [Tabela IV - Comparações entre predições numéricas e valores experimentais da resistência à flexão biaxial de 3Y-TZP.]

\begin{tabular}{cccccc}
\hline Model & $\begin{array}{c}\text { Hoop stress } \\
(\mathrm{MPa})\end{array}$ & $\begin{array}{c}\text { Radial stress } \\
(\mathrm{MPa})\end{array}$ & $\begin{array}{c}\text { Biaxial stress } \\
(\mathrm{MPa})\end{array}$ & $\begin{array}{c}\text { P-3B } \\
(\mathrm{MPa})\end{array}$ & $\begin{array}{c}\text { Difference } \\
(\%)\end{array}$ \\
\hline P-3B_Min & 1116.69 & 1120.06 & 1118.37 & 1092.28 & 2.4 \\
P-3B_Med & 1163.79 & 1161.41 & 1162.60 & 1191.77 & 2.4 \\
P-3B_Max & 1199.71 & 1199.71 & 1199.71 & 1291.26 & 7.1 \\
\hline
\end{tabular}

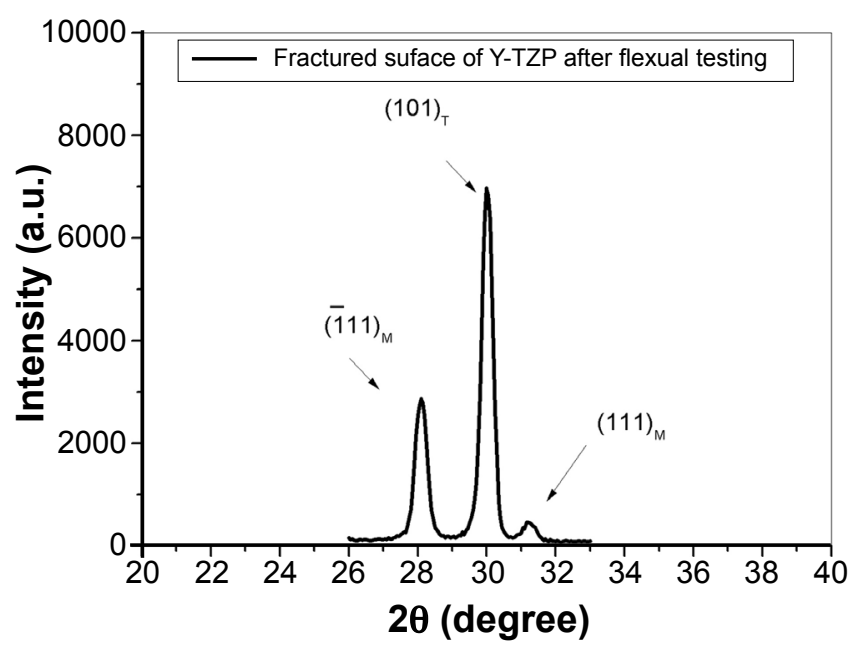

Figure 13: XRD pattern of a typical fracture surface of Y-TZP after $\mathrm{P}$-3B flexural testing ( $\mathrm{M}$ - $\mathrm{ZrO}_{2}$-monoclinic; $\mathrm{T}$ - $\mathrm{ZrO}_{2}$-tetragonal). [Figura 13: Padrão de difração de uma superfície de fratura típica de Y-TZP após o teste de flexão P-3B ( $\mathrm{M}$ - $\mathrm{ZrO}_{2}$-monoclínico; $\mathrm{T}$ $\mathrm{ZrO}_{2}$-tetragonal).]

effect, or ferroelasticity, is the mechanical commutation of twin domains differently oriented under an applied load, greater than the critical material stress, $\sigma_{c}$; this mechanism was studied in detail in sintered Y-TZP using neutron diffraction during compressive mechanical tests [30-31]; since the neutron diffraction makes it possible to obtain diffraction patterns that reach the entire depth within the sample (bulk) and can be conducted in situ during the application of mechanical loads, this technique allows to observe this phenomenon; in these tests, compressive loads with maximum stresses in the order of 2-2.6 GPa were applied, where it was verified changes in the March coefficient (preferential orientation) of tetragonal grains, variations in the distribution of internal deformation of the material and in its tetragonality (c/a ratio of the $\mathrm{ZrO}_{2}$ lattice parameters) at multiple loads; finally, it was possible to observe critical compressive stress of 1.2-1.6 $\mathrm{GPa}$, depending on the content and type of dopant $(\mathrm{Mg}$, $\mathrm{Ce}, \mathrm{Y}$ ) used for $\mathrm{ZrO}_{2}$-tetragonal stabilization, as the critical stress where ferroelasticity allows transformation, and consequently the toughening is enhanced; it was also possible to observe that, before the material rupture, after stressing, the material exhibits relaxation effects (reversal $\mathrm{m} \rightarrow \mathrm{t}$, relaxation of the ferroelastic domain), that is, after compressive load end, the original structural configuration, as well as the initial tetragonality, is recomposed.
During the flexural test of any nature, 4-P, 3-P, P-3B or $\mathrm{B}-3 \mathrm{~B}$ type, the surface of the specimen into which the load is applied is compressed, while the opposite surface, where there are the supports, is submitted to tension. In the biaxial flexure using the three-ball test (P3B), as shown in the present numerical simulations with the finite element method (Fig. 7), the tensile surface is subjected to higher stresses, with the central region of the sample considered the most critical. Assuming 3Y-TZP as isotropic material, entirely composed of $\mathrm{ZrO}_{2}$-tetragonal grains, whose microstructure is composed of monomodal distribution of grain sizes (without exaggerated grain growth), with full density, and residual pores smaller than the critical flaw size, without critical roughness, it is expected that the fracture occurs after the elastic strain reaches a maximum value, that surpasses the toughening mechanisms and reaches the rupture stress of the material. From these considerations, the predictions of the numerical simulations would allow a good forecast with respect to the experimental data. Table IV resumes the comparison between the experimental values of flexural strength and the average values of the radial and circumferential stresses obtained by the finite element models of the P-3B flexural tests.

Experimental results in the batch of sintered samples $(n=23)$ indicated that the tested samples showed good homogeneity, presenting high densification, low surface roughness and a homogeneous microstructure with an average grain size of $0.63 \mu \mathrm{m}$ with low standard deviation $( \pm 0.24 \mu \mathrm{m})$, indicating that there was no exaggerated grain growth during sintering. Thus, most of the grains presented in the bulk of the samples contributed to the toughening mechanisms mentioned above. With this information, it is possible to suppose that the bottom surface of the disc subjected to a state of tensile stress presented a random population of toughened $\mathrm{ZrO}_{2}$-tetragonal grains, around of $71 \%$, as well as other $29 \%$ of $\mathrm{ZrO}_{2}$-cubic grains did not present the toughening mechanisms previously mentioned and, therefore, they behaved with brittle nature. Due to these characteristics, it is understood that these $\mathrm{ZrO}_{2}$ cubic grains were responsible for the rupture stress, obtained in the experimental results presented in Table IV. If a homogeneous and random distribution of these $\mathrm{ZrO}_{2}$ tetragonal grains is considered in the matrix, ferroelasticity may have contributed to increased toughening during load application which the material was subjected during the P-3B test in high stresses. However, when the critical stress 
P. C. Silva et al. / Cerâmica 66 (2020) 30-42

was attained for crack propagation from the $\mathrm{ZrO}_{2}$-cubic grains present in the central region of the tensile surface of the samples (discs, Fig. 7), this would be the preferred region for the propagation and growth of catastrophic cracks in the material. As a consequence, during the propagation of these cracks, the neighboring $\mathrm{ZrO}_{2}$-tetragonal grains would undergo compression, providing volumetric expansion by the transformation $\mathrm{t} \rightarrow \mathrm{m}$, as well as by the microcracking mechanism association. As the load increases, during the P-3B biaxial bending test, the critical stress is exceeded, culminating in ceramic failure, in a configuration similar to that shown in Fig. 8. Fig. 13 shows a typical XRD pattern of the fracture surface of the samples tested, in which it is observed the presence of a substantial amount of monoclinic phase resulting from the $\mathrm{t} \rightarrow \mathrm{m}$ transformation that occurred during the fracture. The differences observed between the experimental and simulated values (Table IV) varied between $2.4 \%$ and $7.1 \%$. These differences were considered low, given the brittle nature of the ceramic investigated (3Y-TZP), and corroborated the quality of the simulations. As the main contribution to the differences between simulated and experimental results, we highlight the crystalline phase quantification, which indicated the presence of $28 \%$ of $\mathrm{ZrO}_{2}$-cubic phase, which did not present effective transformation-toughening mechanisms.

\section{CONCLUSIONS}

Sintered Y-TZP ceramic containing a tetragonal/ cubic ratio of $72 \% / 28 \%$ presented full densification with an average grain size of $0.6 \pm 0.2 \mu \mathrm{m}$. The finite element modeling (FEM) of the biaxial flexural strength using piston-on-three balls (P-3B) test was compared with the experimental results, presenting differences lower than $7 \%$. Differences in bending strength results can be related to the intrinsic phenomena such as $\mathrm{t} \rightarrow \mathrm{m}$ transformation and ferroelastic domain switching, as a function of $\mathrm{ZrO}_{2}-$ tetragonal grain population present in the microstructure. The phase quantification of Y-TZP ceramics must be performed and analyzed with the experimental results whenever finite element simulation techniques (FEM) are used to predict their mechanical behavior, since it is possible that a fraction of non-toughening grains, such as $\mathrm{ZrO}_{2}$-monoclinic or $\mathrm{ZrO}_{2}$-cubic, exhibits a different behavior than the tetragonal $\mathrm{ZrO}_{2}$ matrix, making it difficult to validate the numerical simulations in this ceramic.

\section{ACKNOWLEDGMENTS}

The authors thankFAPERJ (grants n ${ }^{\circ}$ E26-201.476/2014, $\mathrm{n}^{\circ}$ E26-202.997/2017 and $\mathrm{n}^{\circ}$ E26-211.760/2015), CNPq (grants $\mathrm{n}^{\circ} 311119 / 2017-4$ and $\mathrm{n}^{\circ} 305194 / 2015-1$ ) for financial support, Dr. José Eduardo Amarante for SEM micrographs and Christian C.P. Oliveira and Vilcimar Azevedo (undergraduate engineering students) for sample machining. P.C. da Silva acknowledges CAPES for the Ph.D. scholarship program.

\section{REFERENCES}

[1] A. Della Bona, J.R. Kelly, J. Am. Dent. Assoc. 139 (2008) 8.

[2] J.E.V. Amarante, M.V.S. Pereira, G.M. Souza, M.F.R.P. Alves, B.G. Simba, C. Santos, Mater. Sci. Eng. A 739 (2019) 149.

[3] I. Denry, J.R. Kelly, Dent. Mater. 24, 3 (2008) 299.

[4] K.J. Anusavice, Phillips science of dental materials, $11^{\text {th }}$ ed., Elsevier Sci., USA (2003).

[5] ISO 6872, "Dentistry: ceramic materials", Int. Stand. Org. (2015).

[6] R.A. Giordano, L. Pelletier, S. Campbell, R. Pober, J. Prosthet. Dent. 73, 5 (1999) 411.

[7] J. Chevalier, Biomaterials 27, 4 (2006) 535.

[8] J.R. Kelly, I. Denry, Dent. Mater. 24 (2008) 289.

[9] A. Borger, P. Supancic, R. Danzer, J. Eur. Ceram. Soc. 22 (2002) 1425.

[10] S. Rasche, S. Strobl, M. Kuna, R. Bermejo, T. Lube, Proc. Mater. Sci. 3 (2014) 961.

[11] D. Fabris, V.M.J. Souza, F.S. Silva, M. Fredel, J.M. Guimaraes, Y.Zhang, B. Henriques, Ceram. Int. 42, 9 (2016) 11025 .

[12] S. Kabekkodu (Ed.), ICDD Powder diffraction file, Int. Centre Diffract. Data, Pennsylvania (2016) 19073.

[13] H.M.A. Rietveld, J. Appl. Crystallogr. 2 (1969) 65.

[14] R.J. Hill, C.J. Howard, J. Appl. Crystallogr. 20 (1987) 467.

[15] C. Wei, L. Gremillard, Acta Mater. 144 (2018) 245.

[16] B.G. Simba, C. Santos, K. Strecker, A.A. Almeida Junior, G.L. Adabo, Mater. Res. 19 (2016) 829.

[17] ASTM C1327-15, "Standard test method for Vickers indentation hardness of advanced ceramics" (2015).

[18] K. Niihara, J. Mater. Sci. Lett. 2 (1983) 221.

[19] ASTM E1876-15, "Standard test method for dynamic Young's modulus, shear modulus, and Poisson's ratio by impulse excitation of vibration", ASTM Int., West Conshohocken (2015).

[20] J.B. Quinn, G.D. Quinn, Dent. Mater. 26 (2010) 135.

[21] A.A. de Almeida Junior, G.L. Adabo, B.R. Galvão, D. Longhini, B.G. Simba, C. dos Santos, Cerâmica 64, 372 (2018) 491.

[22] C.W. Huang, C.H. Hsueh, Dent. Mater. 27 (2011) e117. [23] F. Zhang, M. Inokoshi, M. Batuk, J. Hadermann, I. Naert, B. Van Meerbeek, J. Vleugels, Dent. Mater. 32 (2016) 327.

[24] R.C. Souza, C. Santos, M.J.R. Barboza, L.A. Bicalho, C.A.R.P. Baptista, C.N. Elias, J. Mater. Res. Technol. 3, 1 (2014) 48.

[25] P.F. Manicone, P.R. Iommetti, L. Raffaelli, J. Dent. 35 (2007) 819.

[26] B. Lawn, Fracture in brittle solids, $2^{\text {nd }}$ ed., Cambridge Un. Press (2010).

[27] F.F. Lange, J. Mater. Sci. 17 (1982) 235.

[28] R.H.J. Hannink, P.M. Kelly, B.C. Muddle, J. Am. Ceram. Soc. 83 (2000) 461.

[29] J. Chevalier, L. Gremillard, J. Am. Cer. Soc. 92 (2009) 
1901.

[30] E.H. Kisi, S.J. Kennedy, C.J. Howard, J. Am. Ceram. Soc. 80, 3 (1997) 621.
[31] Y. Ma, E.H. Kisi, S.J. Kennedy, J. Am. Ceram. Soc. 84, 2 (2001) 399.

(Rec. 26/04/2019, Rev. 12/07/2019, Ac. 13/08/2019) 